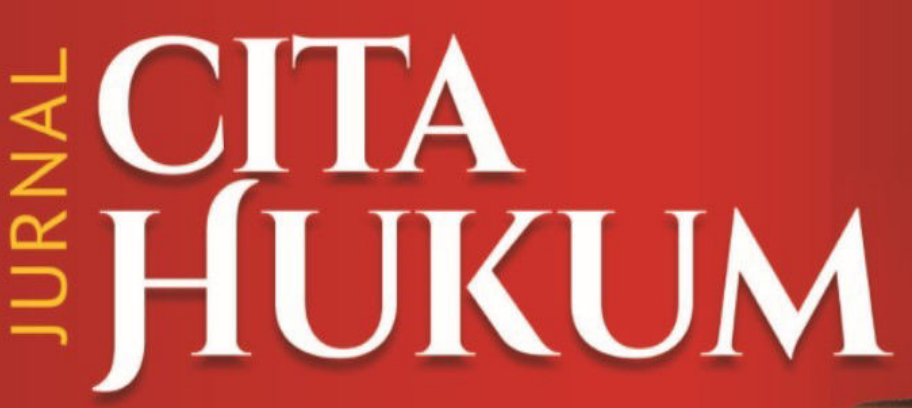

Indonesian Law Journal

- Analysis of the Nature of the Fulfillment of the Obligation in Iran and in France Civil Codes

Zahra Babajani, Saeid Kheradmandy \& Mohamad Javad Jafari. (Islamic Republic of Iran)

- Case Study of The Supreme Court Ruling Number: 3002 K/Pdt/2015 On The Validity of Provision of Income Agreement Which Was Made Before Divorce Based On Civil Code

Hazar Kusmayanti, Tri Utami Warapsari \& Linda Rachmainy. (Bandung, Indonesia)

- Malice in Crimes in Iran and The English Criminal Law

Peyman Rostamian, Mohammad Hossein Hajjarian, \& Hassan Ali Moazzanzadegan. (United Arab Emirates (UAE))

- Legislative Construction of the Post Amendment In Restoring Indonesian Democracy Asep Syarifuddin Hidayat. (Jakarta, Indonesia)

- The Implementation of Supreme Court Regulation Number 2 of 2012 concerning Limitation Adjustment of Mild Criminal Offenses and Amount of Fines in the Criminal Code Towards Handling of Minor Crime Cases

Abbas Sofwan Matlail Fajar \& Mara Sutan Rambe. (Islamic Republic of Pakistan)

- Legalizing Unofficial Marriage for Indonesian Migrant Workers In Malaysia

Afwan Faizin, Alfitra \& Ali Mansur. (Jakarta, Indonesia)

- Emancipation and Legal Justice; Portrait of Women's Legal Protection In Indonesia

Mentari Berliana Kemala Dewi \& Ridwan Arifin. (Semarang, Indonesia)

- The Role of Law on the Implementation of Green Banking in Indonesia Ria Safitri, Hartiwiningsih \& Hari Purwadi. (Surakarta, Indonesia)

- Роль спецслужб в ликвидации неповиновения (мятежных действий) в Индонезии и Филиппинах (Role of Secret Agent Institutions in Eradication of Rebels In Indonesia and Philippines)

Sekar Hapsari \& Saddam Aljihad. (Kazan, Federasi Russia) 


\section{VOLUME 7 NUMBER 1 (2019)}

JURNAL CITA HUKUM is Indonesian Law Journal published by Faculty of Sharia and Law, State Islamic University Syarif Hidayatullah Jakarta in Associate with Center for Study of Indonesian Constitution and Legislation (POSKO-LEGNAS) UIN Jakarta.

This journal specializes in Legal Studies and try to present various results of the latest and high-quality scientific research.

As an International Journal, all articles must be written in English or Russian, because they will be read online by millions of readers, both speakers of English and Russian.

JURNAL CITA HUKUM has been indexed at Web of Science (WOS) Web of Science (WOS) or Emerging Source Citation Index (ESCI) Clarivate Analytics, DOAJ, EBSCO, DIMENSION, Microsoft Academic Search, and SINTA 3 and become a CrossRef Member since year 2015. Therefore, all articles published by JURNAL CITA HUKUM will have unique DOI number.

\section{INTERNATIONAL EDITORIAL BOARD}

Prof. Carolyn Sappideen, Scopus ID: 6506771331 School of Law Western Sydney University, Australia

Prof. Alexander Fedorovich Malyy, Scopus Id: 57194874834 , Department of Constitutional Law, Kazan Federal University, Russian Federation

Prof. Razeen Sappideen, Scopus ID: 14041008300 School of Law Western Sydney University, Australia

Prof. Stanislav Shkel, Scopus Id: 56747984200, Department of Constitutional Law, Ufa State Petroleum Technological University, Russian Federation

Prof. Stefan Koos, Bundeswehr University Munich

Prof. Muhammad Munir, Scopus ID: 54414595100, Department of Law, International Islamic University Islamabad, Pakistan

Prof. Euis Nurlaelawati, Scopus ID: 56247081700, Faculty of Sharia and Law, State Islamic University (UIN) Sunan Kalijaga Yogyakarta

Prof Abdul Gani Abdullah, Universitas Islam Negeri Syarif Hidayatullah Jakarta

Prof. Salman Maggalatung, Center for the Study of Constitution and National Legislation (POSKOLEGNAS), Indonesia

Assoc. Prof. Asep Saepudin Jahar, Scopus ID: 57156653300 , Department of Economic Law Universitas Islam Negeri Syarif Hidayatullah Jakarta

Assoc. Prof. Ahmad Tholabi Kharlie, Thomson Reuters Id: R-5028-2017, Department of Family Law, Faculty of Sharia and Law, Universitas Islam Negeri Syarif Hidayatullah Jakarta

\section{EDITOR IN CHIEF}

Nur Rohim Yunus, Thomson Reuters Researcher ID: F-3477-2017, ORCID ID: 0000-0003-27821266, SSRN ID: 2645355, SINTA ID: 5975443, Department of Constitutional Law, UIN Syarif Hidayatullah Jakarta, Indonesia

\section{MANAGING EDITOR}

Muhammad Ishar Helmi, Thomson Reuters Researcher ID: F-3345-2017, ORCID ID: 0000-0001-7060-8191, SINTA ID: 6199804, Department of Criminal Law UIN Syarif Hidayatullah Jakarta, Indonesia.

\section{EDITORS}

Indra Rahmatullah, ORCID ID: 0000-0002-6160-4225, SINTA ID: 6200500, Department of Economic Law, Faculty of Sharia and Law, UIN Syarif Hidayatullah Jakarta, Indonesia

Fitria Fitria, ORCID ID: 0000-0001-9733-1233, Department of International Law, York Law School, University of York, UK, United Kingdom.

Mara Sutan Rambe, ORCID ID: 0000-0001-5404-6635, SINTA ID: 6200494, Department Criminal Law, Faculty of Law, UIN Syarif Hidayatullah Jakarta, Indonesia. Erwin Hikmatiar, Thomson Reuters Researcher ID: F-3235-2017, ORCID ID: 0000-0003-4103-818X, SINTA ID: 6200141, Center for The Study of Constitution and National Legislation (POSKOLEGNAS), UIN Jakarta.

Arip Purkon, ORCID ID: 0000-0002-6195-9384, Department of Law, University of Malaya, Malaysia.

\section{LANGUAGE EDITOR (ENGLISH AND RUSSIA)}

Raisa Shahrestani, Belgorodsky State University, Russia.

Firsty Izzata Bella, State Islamic University (UIN) Syarif Hidayatullah Jakarta, Indonesia.

\section{ASSISTANT TO THE EDITORS}

Anisaul Kamilah. State Islamic University (UIN) Syarif Hidayatullah Jakarta, Indonesia.

Firda Zahra, State Islamic University (UIN) Syarif Hidayatullah Jakarta, Indonesia.

Redaktur Office

Faculty of Sharia and Law UIN Syarif Hidayatullah Jakarta

Street Ir. H. Juanda 95 Ciputat Jakarta 15412

Phone. (62-21) 74711537, Faks. (62-21) 7491821

Website: www.fsh-uinjkt.net, E-mail: jurnal.citahukum@uinjkt.ac.id.

Link: http://journal.uinjkt.ac.id/index.php/citahukum 


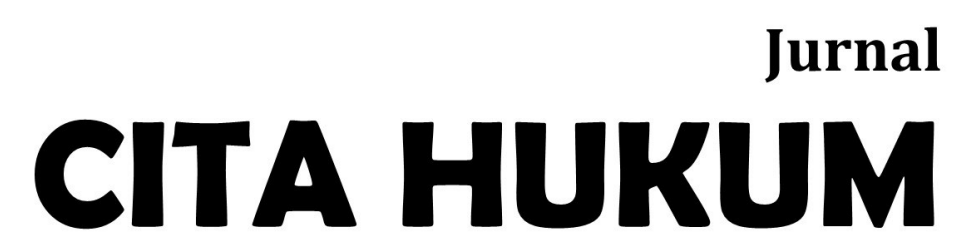

INDONESIAN LAW JOURNAL

Welcoming contributions from scientists, scholars, professionals, and researchers in the legal disciplines to be published and disseminated after going through script selection mechanisms, reviewing sustainable partners, and rigorous editing processes. 


\section{TABLE OF CONTENTS}

Analysis of the Nature of the Fulfillment of the Obligation in Iran

and in France Civil Codes

Zahra Babajani, Saeid Kheradmandy, Mohamad Javad Jafari

Case Study of The Supreme Court Ruling Number: 3002 K/Pdt/2015 On the Validity of Provision of Income Agreement Which Was Made Before Divorce Based on Civil Code Hazar Kusmayanti, Tri Utami Warapsari, Linda Rachmainy....

Malice in Crimes in Iran and The English Criminal Law

Peyman Rostamian, Mohammad Hossein Hajjarian, Hassan Ali Moazzanzadegan $.37-50$

Legislative Construction of the Post Amendment in Restoring Indonesian Democracy

Asep Syarifuddin Hidayat. $51-66$

The Implementation of Supreme Court Regulation Number 2 of 2012 concerning Limitation Adjustment of Mild Criminal Offenses and Amount of Fines in the Criminal Code Towards Handling of Minor Crime Cases

Abbas Sofwan Matlail Fajar, Mara Sutan Rambe. $.67-84$

Legalizing Unofficial Marriage for Indonesian Migrant Workers in Malaysia Afwan Faizin, Alfitra, Ali Mansur.

Emancipation and Legal Justice; Portrait of Women's Legal Protection in Indonesia Mentari Berliana Kemala Dewi, Ridwan Arifin.

The Role of Law on the Implementation of Green Banking in Indonesia

Ria Safitri, Hartiwiningsih, Hari Purwadi.... $115-138$

Роль Спецслужб В устранении Неповиновения или Мятежных Действий В Индонезии И Фидиппинах (Role of Secret Agent Institutions in Eradication of Rebels In Indonesia and Philippines)

Sekar Hapsari, Respiratori Saddam Aljihad. $.139-156$ 


\title{
Malice in Crimes \\ In Iran and The English Criminal Law.
}

\author{
Peyman Rostamian, ${ }^{1}$ Mohammad Hossein Hajjarian, ${ }^{2}$ \\ Hassan Ali Moazzanzadegan ${ }^{3}$ \\ Islamic Azad University, United Arab Emirates
}

doi $10.15408 / j$ ch.v7i1.10720

\begin{abstract}
The presence of a psychological relationship between the act and the agent, and the importance of the intent and the classification of crimes into intentional and unintentional crimes, the punishment of the perpetrators of these crimes differed so that today in the distinction between civil and criminal liability, the condition of the psychological element in the proofs of the titles of criminal acts is necessary, so long as it is said that the principle is the deliberate nature of the offenses and the contrary is required to be specified. Therefore, the current paper aims at investigating the malice in crimes in Iran and The United Kingdom. the conceptual research subject is expanded and then, qualitative research method was used to analyze the data collected from library sources using the legal literature analysis method. The findings indicate that: "The psychological element in Iran and The English Criminal Law is in full compliance in some aspects, while and contradictory others. In addition, The English Criminal Law in some cases is more comprehensive in the field of the psychological element, which, along with the sacred Islamic law, can be useful for Iranian law."
\end{abstract}

Keywords: Crime, Moral pillar, Malice, Iranian law, The English Criminal Law

How to cite (turabian):

Rostamian, Peyman; Hajjarian, Mohammad Hossein; and Moazzanzadegan, Hassan Ali. "Malice in Crimes in Iran and The English Criminal Law," Jurnal Cita Hukum [Online], Volume 7 Number 1 (20 March 2019).

\footnotetext{
Khorramabad, Iran.

${ }^{2}$ Mohammad Hossein Hajjarian is an associate Professor and Faculty Member of Islamic Azad University,

${ }^{3}$ Hassan Ali Moazzanzadegan is an associate Professor and member of the Faculty of Allameh Tabatabai University of Tehran Iran.

*Corresponding Author: rostamian@yahoo.com
}

*Received: Sept 17, 2018, revised: January 8, 2019, accepted: February 23, 2019, Published: March 20, 2019. Emirates (UAE).

Peyman Rostamian is a Ph.D. student of Criminal Law and Criminology, Islamic Azad University, United Arab 


\author{
Kebencian Dalam Kejahatan \\ Perspektif Hukum Pidana Iran dan Inggris
}

\begin{abstract}
Abstrak
Hubungan psikologis antara tindakan dan agen sangat diperlukan, serta pentingnya mengetahui niat dan klasifikasi atas kejahatan menjadi sebuah kejahatan yang disengaja dan tidak disengaja. Selain hukuman dari pelaku kejahatan ini berbeda hingga saat ini dalam perbedaan antara pertanggungjawaban perdata dan pidana, serta kondisi unsur psikologis dalam pembuktian hak atas tindakan pidana yang diperlukan. Sehingga dapat dikatakan bahwa prinsipnya adalah sifat pelanggaran yang disengaja dan sebaliknya harus ditentukan. Oleh karena itu, makalah ini bertujuan untuk menyelidiki kejahatan dalam kejahatan di Iran dan Inggris. Subjek penelitian konseptual diperluas dan kemudian, metode penelitian kualitatif digunakan untuk menganalisis data yang dikumpulkan dari sumber perpustakaan menggunakan metode analisis literatur hukum. Temuan menunjukkan bahwa: "Unsur psikologis di Iran dan Hukum Pidana Inggris dalam kepatuhan penuh dalam beberapa aspek, sementara dan lainnya bertentangan. Selain itu, Hukum Pidana Inggris dalam beberapa kasus lebih komprehensif dalam bidang unsur psikologis, yang bersama dengan hukum Islam yang sakral, dapat bermanfaat bagi hukum Iran."
\end{abstract}

Kata Kunci: Kejahatan, Pilar Moral, Malice, Hukum Pidana Iran, Hukum Pidana Inggris

\title{
Злобные преступления
}

в Иране и Английский уголовный закон

\begin{abstract}
Аннотация
Согласившись с необходимостью наличия психологической связи между деянием и агентом и важностью умысла и классификации преступлений на умышленные и непреднамеренные преступления, наказание лиц, совершивших эти преступления, было разным, поэтому сегодня в различие между гражданской и уголовной ответственностью необходимо наличие психологического элемента в доказательствах названий преступных деяний, при условии, что говорится, что принцип - это преднамеренный характер преступлений, и требуется указать обратное. Таким образом, настоящая статья направлена на расследование преступлений в Иране и Великобритании. Сначала концептуальный предмет исследования расширяется, а затем, качественный метод исследования был использован для анализа данных, собранных из библиотечных источников с использованием метода анализа юридической литературы. Полученные данные указывают на то, что: «Психологический элемент в уголовном праве Ирана и Англии полностью соответствует в некоторых аспектах, хотя и противоречит другим. Кроме того, Уголовное право Англии в некоторых случаях является более полным в области психологического элемента, который, наряду со священным исламским законом, может быть полезен для иранского права».
\end{abstract}

Ключевые Слова: Преступность, Моральная Опора, Злоба, Иранское Право, Английское Уголовное Право 


\section{Introduction}

From a legal point of view, malice expresses the deliberate intention of an illegal act (Beigi \& Naghibi, 2015: 3). In the United Kingdom, criminal law is the product of a common law in which the law is made by judges. The common law consists of the common general rules that have long been agreed upon by the public and considered as the law of the country by their practice in courts. One of the common laws that were introduced as a result of the practice of The United Kingdom courts in malice. However, this is in Iran's criminal law is about intentional crimes, and what is decisive in determining the intentional nature of a crime is its intent or perilous behavior, or the circumstances of the offender. The Islamic Penal Code of 2013, while accepting the traditional principle of unintentional crime, by adding a note to Article 292, partially disturbs the equation and restricts the scope of unintentional crime in some cases. Having abandoned the criteria such as the action intent and the intent of the result to the victim without the need for fault and taking into account the awareness and attention to the occurrence of a crime against another, the crime of unintentional crime, in fact, has been taken deliberately. The content of this statement is conceptually is not unrelated to the theory of malice in The United Kingdom (Beigi \& Naghibi, 2015: 4, 21). Given this review, what has highlighted the importance of this paper is that today, unintentional crimes and even absolute and material crimes, constitute a large part of the rules and regulations of criminal law. As a result, given the important role that this concept has, their exact recognition, and the determination of the scope and extent of the offenses and the distinction of these crimes from intentional crimes seem necessary. According to the necessity of research, the main objective of this paper is the comparative study of the similarities and differences, the concept and examples, theoretical foundations and the effects of the concept of malice crime in Iran and The English Criminal Laws. According to the necessity of the research and purpose of the paper, the main question is: What is the legal basis of malice crimes in Iran and The English Criminal Laws?

\section{Research Innovation}

The current paper aims at investigating the differences and similarities of various malice crimes in Iran and The English Criminal Laws while investigating the basis of the psychological element in the rights of England and Iran. In the other part, the topic of malice is investigated in unintentional crime, and then malice in financial crimes are addressed. In the end, documents of intentional malice 
and its barriers have been investigated in cases such as drunkenness, reluctance, urgency and coercion, the issues rarely investigated.

\section{Malice in crime}

Given the United Kingdom criminal law, it can be argued that the cause of a number of criminal laws from the sixteenth century through the eighteenth century and the imposition of capital punishment to a large number of criminal offenses, in particular, the various forms of theft and robbery, have been considered. The brutal law that peaked at the beginning of the nineteenth century is due to the lawlessness that grew significantly before the formation of an organized police system, but with the development of legal trends in the world and in the United Kingdom, the criminal laws finally went in the growth and development path until, the elements and factors influencing the crime have been completed and the process has grown (Lyon Cross, 2018: 544-560). Accordingly, it can be said that incitement behavior is considered as a crime where its constituent elements are realized, and for the purpose of being punishable as a crime, the collection of several essential elements is necessary (Mohseni, 1996: 23).

Some of these elements are public, that is, they are mandatory in all crimes, and some have a specific aspect. Some legal experts state that "an act in order to be considered a crime, should first, by law, to be prosecuted and punishment assigned to it (the legal element); second, the act or the detention of the act, be specific to a circumstance, not an imagination that has not become actuality. (Material element), third, it should be committed with the intention of a criminal offense (physiological element)" (Sanei, 1993: 174).

The physiological element (malice) is one of the constituent elements of crime, which is used among legal experts in two broad and limited meanings. The psychological element of intentional crime in the limited sense includes arbitrary offenses or offenses that the perpetrator of the offense is considered, and unintentional offenses involve arbitrary offenses, including offenses due to negligence, but the psychological element in the broad sense, in addition to the limited meaning, includes criminal liability (Karami, 1998: 11). Human behavior is punishable when accompanies criminal intent or criminal fault, the misconduct is reasonably and rationally unacceptable and defamatory. Of course, the amount of punishment must be different in terms of criminal intent or criminal fault. However, intentional or unintentional crime may have the same results. The will is an inner activity guides the material movement, and every action is rooted in 
an esoteric will, and if the will moves towards an illegitimate aim that the legislator has banned it, it is called a criminal offense. If the moral element of crime or malice or criminal intent is realized, there are various stages that are called goal, purpose, will, and motivation (Zeraat, 2006: 196). An act in order to be a deliberate criminal action should constitute the will of the agent, and if the offense, including the offenses, committed to the result the result also must be intended. Will has two steps. The first step is to choose the way to reach the goal, and the second step is to rule the body members until the goal is reached (Gopanchi, 2004).

\section{The Jurisprudential Concept of Intentional Malice}

It has previously been mentioned that the pillar of the crime has two main forms. One face the criminal intent and the other is the fault. Accordingly, crimes are also classified as intentional and unintentional forms. Criminal intent consists of two elements: knowledge and will. These elements are present in both moral cases, namely criminal intent and fault. Nevertheless, their scope varies in intentional and unintentional. In the intentional crimes, the perpetrator has both knowledge and willpower in relation to all material components, but in the case of fault, his knowledge and will constitute only part of these elements, and the offender only has the possibility of realizing it, or, at the time of committing behavior, they should be able to realize them (Bernard, 1950).

\section{Intentional crime}

The jurisprudential books have discussed the causes of retaliation for intentional crimes and, in the definition of the murder, have often said, with a brief distinction: "killing causes retaliation that is the murder of a respected and equal soul deliberately and adventitiously"(Heli, $670 \mathrm{AH}$ : 195). The deliberate murder is that the subject intends to kill and kills as intended, whether it is direct or indirect intent to the general (non-determinative) or partial (definite) object, and with procuration, or indirect destruction, or both. Or, in other words, a murder occurs when someone kills someone else illegally with the intention of killing or harming him (Flatley, 2018: 17-20)

\section{Intent}

First, it is important to note that "criminal justice is willing to differentiate between a murderer deliberately killing and a killer who merely intends to kill 
one person and accidentally killed another person. Both murders must be punished for the two murders, but the first one clearly implies more guilt" (Rpptr, 2014: 635). This statement well demonstrates the intent (malice). It should be noted that in crimes what is a criterion in general maladministration, the intention of the act is to put it against the innocent, and therefore, in the intentional act, it is necessary to consider two basic points. First, the crime was committed to as intended by the offender, and, second, the act has been targeted to a person who is intended to be targeted.

\section{Analysis of Shiite Jurisprudential Views On The Moral Element of Crime}

Over time, a new attitude was created that, in addition to crime and harmful acts, the perpetrator and his personality should also be considered, and since that time, the moral element has been raised in the context of criminal law proceedings. Nowadays, when prohibited acts occur, it is obvious and essential obtaining the moral element and the criminal responsibility in the proceedings (Milani \& Abdolkarimi, 2015: 73). Therefore, jurisprudence, without the use of the term "offense", deals with the definition of acts viable to Tazzir and punishment. For example, some statements read committing greater sins and insisting on lesser ones requires Tazzir; another statement reads that the commission of the act of haram and avoidance for the obligatory with no punishment "Had" assigned to in Sharia requires Tazzir. Accordingly, the crimes in jurisprudence are either physical offenses ae often referred to as "crimes" and involve retaliation or diya, or crimes that are punishable under Sharia Law, which is referred to as "hodod", and in otherwise, they will have the title "Tazzir" (Abu Zuhra, 1998: 545).

\section{Malice in Crime in Iran}

Intentional crimes require criminal intent, and the criminal intent of the will (the will of physical behavior and the result of a criminal offense) and knowledge (knowledge of the pillars). Malice, misconduct, intent, and knowledge have been used in various Criminal Code paragraphs in a sense that involves criminal intent. The intent is the will of a man guiding him/her in intentional offense prohibited by law. Therefore, in the intentional offenses, both the act and the result areintended by the offender will. In other words, if the perpetrator has anticipated the result of the action attributed to him, and if he has acted in accordance with the criminal outcome, he or she has intentionally committed the crime (Goldozian, 2005: 208). The crimes in another classification, in terms of the 
nature of the crime, have become classified into public, political, and military. Public crimes are considered as crimes that people are able to commit and, in general, harassing their minds, such as murder and robbery (Rahiminejad, 1993: 43), while harming the physical integrity, morality and private interests of individuals.

\section{Theoretical Foundations of Malice in Crime in The English Legal System}

In the English Legal System, the purpose of particular malice (indirect) is the intention of a result of a natural consequence (on the basis of the rational probability that the mystics are at the level of certainty or suspicion of knowledge) on the person's behavior. The UK, Law Article 3, paragraph 1, states that "If one assumes that the events and circumstances are such that he commits a crime, he must have the intent to commit the crime"(Berzi, 2014: 154). It is logical to say that the intent in such behavior is as a result of the intent to do so and the intent has been implicit "or" committed "in the perpetrator. Generally, from the "supplies" of committing that behavior, it has been the occurrence of a definite result; so that, the perpetrator has predicted it at least in committing way, and has been aware of it. The next stage is indifference to the level of malice: an individual commits criminal behavior in spite of the rational and conventional possibility of obtaining the result (or in another word probably). That is why some writers have considered the interference or negligence in the realization of an intentional criminal offense only in offenses with definite results (Fletcher, 2005: 197); that is, the perpetrator predicted the outcome or, conventionally could have predicted the outcome, but nevertheless did commit a criminal offense. In the English Criminal Law, as well as the US Penal Code, it has been emphasized that the probable outcome must be predictable, and the danger and the detriment must have been important and obvious (Khaleqi \& Rajab, 2013: 128).

\section{M'Naghten Rule}

"In order to prove the defense of madness, it must be clearly and conclusively proved that at the time of committing the act, the accused suffered from such a moral defect, caused by a moral illness, who did not know the nature and quality of what he was doing, or, if he knew, he was not aware of it. We believe that he should be considered in the same state of responsibility as if the facts were true about this actual illusion" (Asli, 2001: 84). 


\section{Durham rule}

"If the unlawful act of the accused is a product of mental disease, it will not be punishable by a criminal offense." Without doubt, this view is far better than the M'Naghten Rule and the term "irresistible motive" is better because it explicitly refers to nature, the quality and the fault and the "irresistible motive" do not mention, and hence covers the broader scope. The Durham rule consists of two questions: 1). Did the accused suffer mental disease or intellectual impairment when committing his or her actions? 2). Is his action the product of this mental disease or intellectual deficiency? This view has been taken in the United States, as well, causing many psychiatric patients who are not insane, but lacking the power to inspect their behavior, to be exempted from criminal liability.

\section{Malice in The English Criminal Law}

At present, Britain is known as a monarchical parliamentary system, and the separation of powers is relative. In other words, although each of the three powers has their own legal duties and powers, they have the legal means to balance and interact with each other (Constant, 2010: 45). Britain, which is accustomed to the rule of law over the years and centuries, has so far not been able to rid itself of this tradition. For them, the rule of law does not exist in truth except from the point of view of the events of a lawsuit about what is necessary to resolve a dispute. The pursuit of a traditional common law does not only create a problem but also precludes joining the Roman-Germanic system of law (Ewing, 2006: 42).

\section{Common Law}

The laws and regulations applied by the King tribunal in similar cases throughout the country, and were not assigned to a particular area and place, were called Common Law. In the course of centuries, the previous views were effectively followed in the next cases, without such a requirement legally binding. Common Law is the basis of British law, and it is commonplace because of the commonality of this system for all parts of England and Wales. These laws include the rules and conventions of England that have been legally recognized by judges since the previous judgments in certain cases brought before them. The dual material and psychic pillars are based on different types of crime in criminal law, which can be either common law or legal in the English legal system. 


\section{Public Crimes (Crimes Based on Common Malice)}

In general, it can be said that the way individuals interfere in the commission of a crime may be one of the three forms of aiding, abetting, or participation (Rahmdel, 2010: 161). In order for the English Courts of Justice to be able to convict a person as a crime aiding, it is necessary to determine and apply one of these examples to the behavior of the deputy and to mention it in the sentences.

\section{Murder}

The intentional murder, and in particular its penalties, which are among the most severe criminal penalties in the two legal systems of Iran and the United Kingdom, are considered to be major and important crimes. Each of the two systems, by adopting various laws and regulations, has tried to prevent this crime but unfortunately, despite the efforts made, people are still witnessing it. It is not much new in the Penal Code, the United Kingdom abandoned death penalty, but attempted, all aimed at reducing the intentions of deliberate murder and the withdrawal of some deliberate acts of intentional murder, which in Iran's law are definitely considered murderous instances. (Emami, 2014: 5). In British law, it is believed that minors and insane cannot commit murder in no way because they are incapable of committing a crime. The root causes of child and insane issues, including these individuals delinquencies, are an essential condition in order to achieve an ideal community.

\section{Rape}

Some writers also mean that the rape referred to in the crimes such as adultery, sodomy, illegitimate relations and the like (Zeraae \& Mohajeri, 2007: 169). In these opinions, the illegitimate relationship and the practice of disparagement of chastity are equally assumed; while, in some cases, the presence of the phrase "or" between the two terms "illegitimate relationship" and "action of disparagement of chastity" indicates that the legislator has been separated the two items from each other (Nayeri, 2009: 119). One of the most striking points in British law in the field of rape is the issue of rape by a spouse against women. This is despite the fact that in none of the laws of the Iranian legal system, such a crime has never been foreseen. In the British legal system, there is also no largescale investigation of rape or rape in England.

In the English legal system, liability for damages from crime was limited to compensation. As these laws focused more on home protection and supply of 
food and property destruction. In the Criminal Code of 1971, three types of criminal compensations have been taken into consideration. These damages include simple criminal damages, severe criminal damages, and criminal damage caused by fire, threatening to eliminate or damage to property belonging to another. The maximum punishment for criminal damage and fire are life imprisonment. The maximum penalty for other crimes is 10 years.

\section{Malice Crimes in The English Legal System}

In England's criminal law, fraudulent gain, as an example of fraud, has been criminalized as an independent criminal offense. Article 16 of the 1968 theft law was cited as a crime for obtaining cash benefits by deception. In accordance with article 16, paragraph 1, of the person who deceived fraudulently any cash benefits for himself or herself or another, or the prosecution was sentenced to a maximum of five years in prison.

Acceptance of the "takeover" element as the main pillar of the crime of robbery in English law makes it difficult to distinguish precisely between this crime and crimes such as fraud, destruction, and even interference with the stolen property. In each of these cases, it is also customary to commit the wrongdoing with ownership of property rights is taken over by them. In order to resolve this problem, English courts have tried to differentiate between these different types of offenses in several cases. And, of course, the basis for their decisions has been criticized by lawyers. In English law, the psychological element of stealing from two parts of the general purpose, meaning intent in the possession of property, and a particular site, means the intention to permanently deprive the owner of the property, and this recent issue is explicitly mentioned in the text of the theft law (Sadeghi, 1997).

\section{Unintentional Crimes}

The concept of intent is in line with both Iran Law and Common Law, but heedlessness is an unknown concept in Iranian law, and we do not have the exact equivalent for. A heedless person is doing something that can harm others' lives and property. In fact, it carries out a practice in which there is a danger, and this risk is untenable (Esgalakki \& Wahabi, 2011: 82). Now, if a person is aware of this danger and at the same time he is acting, he is Cunningham heedless (or person); but if he performs an unjustifiable risky action that he is not aware of at risk, but a reasonable and reasonable person, perceives it as dangerous, he is called a 
Caldwell (or some kind), and thus deserves to be punished. Neglect also means that a person performs an unjustifiable act that causes damage to another's life and property, whether he has been or may not have been aware of the outcome. In fact, here too, the criterion of criminal liability, like Caldwell's heedlessness, is consistent with the standard of "normal man."

In Common Law, the objective criterion has been accepted as the criterion for recognizing the psychological element of some limited offenses, such as sexual offenses, unintentional murder based on gross neglect and risky driving. In contrast, this maximum concept of no-fault criminal liability, which according to the jurisprudence of criminal Common Law lawyers is generally absent from any criminal case without the maximum fault, is not even defendable, there is another level of blamelessness that now In the English Penal Code, in particular, the United Kingdom, is a form of criminal liability. At this minimal level, liability without blame requires not only the presence of two necessities of obtaining the material element and the intervention of an existing will in the emergence of criminal behavior and in a rational and psychological environment, but also somewhat needing a fault in relation to some elements of the material element of the crime.

\section{Conclusion}

Nowadays, unintentional crimes and even mere financial crimes are subjects of a large portion of criminal laws and regulations, and as a result, due to the important role that this implies, their exact recognition, and the determination of the scope of the offenses, as well as the distinction between these intentional crimes is more than necessary. Therefore, the current paper concludes that: first, although both the legal systems of Iran and the United Kingdom have adopted the notion of malice in crime, the examples, and forms of this concept, along with having many similarities, are different. The current paper has investigated these similarities and differences, examples and theoretical foundations and the effects of this fundamental pillar. Secondly, crimes in both the legal system of Iran and Common Law can be classified into psychological pillars. There have been relatively rigorous investigations into intentional crimes and elements, their terms and conditions. But it seems that it has not been as scientific as the intellectual element of unintentional crimes. Thirdly, legal experts state that penalties are based on a fault, that is, someone who has committed a crime with the intention of committing an offense must be liable for the criminal offense. In some cases, the legislator does not recognize the criminal acts committed by the 
aggregation of the three elements constituting the crime, and cannot be attributed to the perpetrator of material acts.

In England, the moral pillar is the same as Iran, with the difference that the particular malice in England is the permanent or temporary exclusion of the rightful owner of some property from property rights, but the particular misconduct in Iran is intended to harm the owner of the property. So, in Iran, the criminal should intent to steal. But in England, one has to take possession. Fourthly, it can be said that although the notion of malic has been accepted in both Iran and the United Kingdom, the examples and forms of this concept, along with having many similarities, have different meanings. In summary, the results show that the moral element in Iran and England Laws in some aspects has a similarity and a complete adaptation, and in some aspects are different and contradictory, and also the England Law. Iran and England Laws in moral component in some cases are more comprehensive, which along with the holy Islamic law can be useful for Iranian law, and this can be a new chapter in legal research aimed at optimizing the legal system of Iran by comparative study and using the dimensions consistent with Iranian-Islamic culture in the world's famous legal systems, including Common Law.

\section{References:}

\section{A. Books}

Abuzahrah, M. Compensation and penalty in Islamic Law, Dar al-Fakir al-Arabi, Cairo, Egypt, 1988.

Aji, A.M.; Yunus, N.R. Basic Theory of Law and Justice, Jakarta: Jurisprudence Institute, 2018.

Rahiminejad, I. Introduction to Criminal Law and Criminology, 1, Qom, 1999.

Zeraat, A.; and Mohajeri, A. Criminal Procedure, Volume I, Tehran, Farkasazan Publications, Third Edition, 2007.

Maggalatung, A.S.; Aji, A.M.; Yunus, N.R. How The Law Works, Jakarta: Jurisprudence Institute, 2014.

Mohseni, M. General Criminal Law (Criminal), C 2, First Edition, Tehran, Ganj Danesh, 1996.

Sadrat, A. Criminal Law and Criminology, First Edition, Tehran, Marefat Center, 1961. 
Constant B. Passion for Freedom, Translator: Abdul Wahab Ahmadi, Tehran, Publication: Agah, 2010.

Fletcher, G.P. Basic Concepts of Penal Law, Translated by Seyyed Zadeh Sani, Seyyed Mahdi, First edition, Ghos-e Razavi pub, 2005.

Sadeghi, M.H. Crimes against individuals (physical injuries), Tehran, Mizan, 2010.

Goldozian, I. General Penal Law, Tehran, Mizan, 2005.

Helli, M. Shira's al-Islam, Ismaili publishing, Vol. 4, $670 \mathrm{AH}$.

Parviz, S. General Penal Law, c.1, fifth edition, Tehran, Ganj Danesh, 1993.

\section{B- Articles}

Esgalakki, J.; and Wahabi, T. "Tochaayi Wahhabi, Mojtaba, Unconscientious Diagnosis of Criminal liability," Jurisprudence and Islamic Law, Volume 3, Issue 4, Summer, 2011.

Nayeri, H.Z.; Reza, M. "Investigation of Offenses of Chastity," Lawyers of Justice, No. 67, 2009.

Khaleghi, A.; Rajab, M.A.; "Subjective Analysis in The Moral Element of The Crime of Intentional Murder (Comparative Study)," Criminal Law Research Journal, No. 7, 2013.

Kodakrami, N. "Analysis of the moral element of crime, the views of the judicial system", Summer and Autumn, No. 10 and 11, 1998.

Asli, M.R. Comparative analysis of madness defense in the United Kingdom, Canada, United States and France, the forty-fifth year, New Period, Dec., No. 28, 2001.

Rahmdel, M. Notes on Aiding Offense, Free Legal Investigations, Nos. 8, 9, and 10, 2010.

Gopanchi, H. Error in the Victim of Crime, Law of Justice, No. 4, 2004.

Beigi, G.; Majid; Naghibi; Reza, S.M. Transferred malice theory, in English Law and its comparison to Iranian Law, Judgment Quarterly, No. 84, 2015.

Mohseni, M. General Penal Law, Vol. 3, First Edition, Tehran, Ganj Danesh, 1996.

Milani, A.; and Abdolkarimi. An Introduction to Criminal Liability without Fault, Quarterly Journal of Social Science Studies, Volume 1, Issue 1, 2015. 
Ewing, B. The References and Nature of the English Constitution, Translation of Tavakol Habibzadeh, Journal of Basic Law, Year 4, No. 6 and Seventh 2006.

\section{C- Thesis}

Emini, M. Comparative Study of Intentional and Unintentional Murder In Iranian And English Law, Master's thesis, Islamic Azad University, Central Tehran Faculty of Law and Political Science, 2014.

Wahhabi, T. "Comparative Study of the Moral Element of Unintentional Crimes in the Law of Iran and the Common Law System," Master's Thesis, Gilan University, 2011.

\section{Internet references}

Sadeqi, H.M.M. Theft in the Iranian and British Laws, 1997.

http://www.ghavanin.ir /PaperDetail.asp?id=844

\section{Foreign References}

Cross, A.L. The English Criminal Law and Benefit of Clergy during the Eighteenth and early nineteenth Century, The American Historical Review, Vol. 22, No. 3, 2018.

Flatley, J. Homicide in England and Wales: Year Ending March 2017, national statistics, 2018.

Rpptr, Cal. California Criminal Jury Reports Instructions> Homicide, 562. Transferred Intent, 2014.

Herzog, J.B. La prevention des infractions involontaires la vie et lintegrite de la personne hummaine, in la prevention des infractions involontaires contre la vie et linteg rite de la personne hummaine, in la prevention des infractions contre vie humaine et lintegrote de la personne, vol. 1, 1950.

Pozen, D.E. "Constitutional Bad Faith", Harvard law review, vol 129, number 4, 2016. 
in Collaboration with :

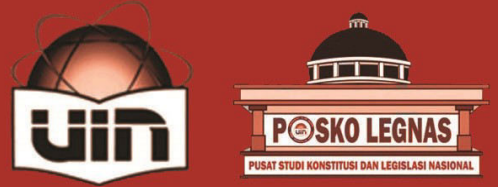

Indexed by :
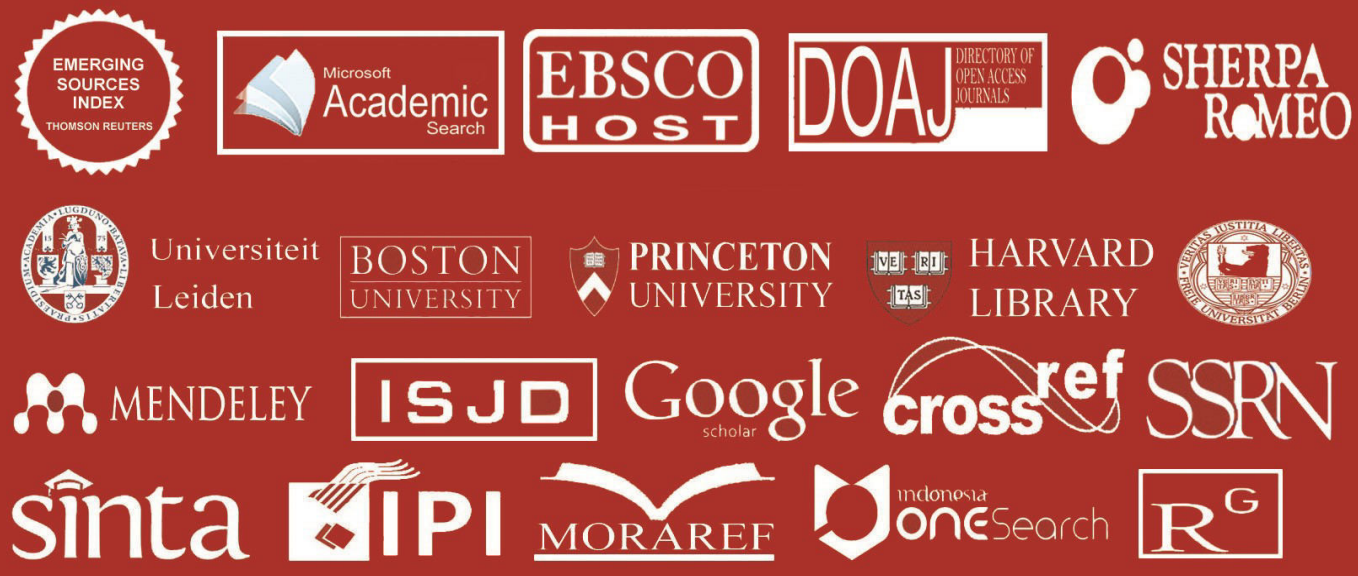

JURNAL CITA HUKUM is a peer-reviewed journal on Indonesian Law Studies published biannual (June \& December) by Faculty of Sharia and Law Universitas Islam Negeri Syarif Hidayatullah Jakarta in cooperation with Center for the Study of Constitution and National Legislation (POSKO-LEGNAS). JURNAL CITA HUKUM aims primarily to facilitate scholarly and professional discussions over current developments on legal issues in Indonesia as well as to publish innovative legal researches concerning Indonesian laws.
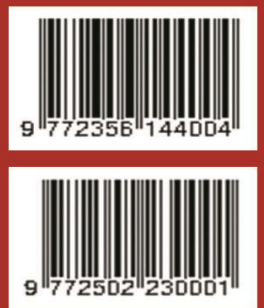